\title{
Cyprian Norwid w Crystal Palace albo czy istnieje światopogląd modernistyczny Norwida?
}

Jest coś prawdziwie niepokojącego w niedostrzeganiu przez współczesnych norwidologów uwikłania ich dyscypliny w problematykę modernizmu. Oczywiście, możemy wyróżnić badaczy tak zwanego modernizmu Norwida, na czele z Wiesławem Rzońcą, autorem książki Premodernizm Norwida - na tle symbolizmu literackiego II połowy XIX wieku (2013)1, którego stanowisko w sprawie Norwida jest skrajne, ale może przez to - symptomatyczne. $O$ wiele bardziej stonowane, umiarkowane poglądy na ten temat przedstawiają w tej „wewnątrznorwidologicznej” debacie mówiący o Norwidzie nowoczesnym Michał Kuziak oraz Sławomir Rzepczyński². To Rzońca jednak doprowadza do polaryzacji stanowisk i prowokuje nierzadko zażarte polemiki. Bywa, że emocje biorą górę - tak jak ma to miejsce w ostrej filipice Edwarda Kasperskiego pod tytułem Pseudo-Norwid, czyli co się komu podoba ${ }^{3}$, skierowanej przeciw „premodernistycznej” książce Rzońcy. Ażeby uzasadnić postromantyczny, nie zaś modernistyczny rodowód światopoglądu Norwida, Kasperski sięga do samych źródeł romantyzmu jenajskiego, wskazując cechy estetyki specyficznie schellingiańskiej wpisane w światopogląd romantyczny Norwida i go gruntujące 4 .

Norwid jako spadkobierca, ,późny wnuk”, dziedzic myśli jenajskiej to zaledwie jeden z argumentów wysuwanych w literaturze przedmiotu na rzecz twórczej anachroniczności autora Quidama. Inny znajdziemy w serii prac istniejących

* Dr, lewks@wp.pl, Wydział Polonistyki Uniwersytetu Warszawskiego, Instytut Literatury Polskiej, Zakład Literatury Romantyzmu, ul. Krakowskie Przedmieście 26/28, 00-927 Warszawa.

${ }^{1}$ W. Rzońca, Premodernizm Norwida - na tle symbolizmu literackiego II połowy XIX wieku, Wydawnictwo Wydziału Polonistyki UW, Warszawa 2013.

${ }^{2}$ M. Kuziak, Norwid i pejzaż nowoczesności. Wokół Paryża poety, „Studia Norwidiana” 2014, nr 32, s. 61-81 oraz S. Rzepczyński, Norwid a nowoczesność, w: Romantyzm i nowoczesność, red. M. Kuziak, Universitas, Kraków 2009, s. 185-215.

${ }^{3}$ E. Kasperski, Pseudo-Norwid, czyli co się komu podoba, „Studia Norwidiana” 2014, nr 32, s. $290-325$.

${ }^{4}$ Nie tylko w tekście Pseudo-Norwid... (m.in. na s. 292), zob. także: E. Kasperski, Słowne obrazy Norwida. Szkic z poetyki komparatystycznej, w: tenże, Kategorie komparatystyki, Wydawnictwo Wydziału Polonistyki UW, Warszawa 2010, s. 263-265 (o Fichtem), 266-268 (o Schellingu). 
w norwidologii od dłuższego już czasu, wskazujących na klasycystyczny rodowód myśli Norwidowskiej ${ }^{5}$. Niedawno zresztą przeżyliśmy, i to po raz kolejny już, renesans tej ścieżki badawczej ${ }^{6}$. Klasycyzmowi Norwida nie przeczy także Rzońca, uważając, że jest on istotnym składnikiem światopoglądu modernistycznego autora A Dorio ad Phrygium ${ }^{7}$. Zarazem - jego samego tezy na temat modernizmu Norwida są postponowane, jego metodologia zaś - w najlepszym przypadku bywa uważana za niehistoryczną, to jest nieneutralną w obrębie dyscypliny historycznoliterackiej, jaką jest norwidologia. Aby to zobrazować, posłużmy się odpowiednim przykładem. Michał Kuziak nazywa Rzońcę twórcą ,komparatystyki antylogocentrycznej". Konstatacja tego rodzaju jest ambiwalentna, choć ma wydźwięk komplementu, jeden badacz Norwida docenia prekursorstwo drugiego, nazywa je i kodyfikuje, ale wymownie... lokuje to prekursorstwo poza norwidologią.

Czemu więc dyskusja na temat światopoglądu modernistycznego Norwida w przeciwieństwie do równoległych dyskusji na temat klasycystycznych czy romantycznych elementów światopoglądu autora Assunty jest nieustannie marginalizowana? Być może nie jest ona jeszcze (bądź już) przedmiotem norwidologicznego tabu, ale bez Rzepczyńskiego, Kuziaka czy Rzońcy o wiele łatwiej byłoby o taką „tabuizującą" konstatację. Zaryzykowałbym zresztą stwierdzenie, że nie w pełni rozumiemy nawet romantyzm Cypriana Norwida. Coś chyba mówi na ten temat wyraźne, wyraziste wręcz dążenie Kasperskiego do ,jenaizacji” polskiego poety, jest ono, jak się zdaje, przejawem szukania przez badacza antidotum na Norwida romantycznego, romantycznego na sposób Mickiewiczowski, którego „pół-Mic-

${ }^{5}$ Wymieńmy te najnowsze, różnicując jednak prace poświęcone tzw. antykowi Norwida i te, które koncentrują się na temacie neoklasycyzmu poety. Ścieżka antyczna: T. Mackiewicz, Sokrates Norwida. Kontekst - recepcja - kontynuacja, Wydawnictwo Wydziału Polonistyki UW, Warszawa 2009, M. Junkiert, Grecja i jej historia w twórczości Cypriana Norwida, Wydawnictwo Naukowe Uniwersytetu im. Adama Mickiewicza, Poznań 2012; ścieżka klasycystyczna: R. Fieguth, Od „Pompei” do „Quidama”. Z problemów klasycyzmu norwidowskiego oraz K. Trybuś, Norwidowski klasycyzm-zarys problemu, w: Klasycyzm. Estetyka-doktryna literacka - antropologia, red. K. Meller, Wydawnictwo Neriton, Warszawa 2009, s. 345-374, 375-390.

${ }^{6}$ Skutkiem rozwoju zainteresowania klasycyzmem w twórczości Norwida są właśnie artykuły na ten temat w tomie: Klasycyzm. Estetyka - doktryna literacka-antropologia pod red. K. Meller (Wydawnictwo Neriton, Warszawa 2009).

${ }^{7}$ Wskazywanie na klasycystyczne cechy Norwidowskiego warsztatu odbywa się u Rzońcy dwubiegunowo: $\mathrm{z}$ jednej strony podkreśla badacz to, że „w wymiarze stylu modernizm w Polsce musiał być przede wszystkim neoromantyzmem, we Francji zaś mógł być neoklasycyzmem", z drugiej natomiast sugeruje, że „być może nie przypadkiem fascynowali Norwida ci, których francuskość była czymś więcej niż cechą stylu". Właśnie ze względu na francuski neoklasycyzm Rzońca stwierdzi więc w konkluzji swojej myśli, że „tworząc nowy model poezji, Norwid kierował literaturę polską na nowo w stronę Francji” - W. Rzońca, Modernizm Norwida-paryżanina wświetle młodopolskiego neoromantyzmu (Paul Verlaine w ujęciu Tadeusza Żeleńskiego), w: tenże, Premodernizm Norwida..., s. 134-136.

${ }^{8}$ M. Kuziak, Palimpsesty komparatystyki, w: Komparatystyka dzisiaj, t. I: Problemy teoretyczne, red. E. Szczęsna i E. Kasperski, Universitas, Kraków 2010, s. 138. 
kiewiczowski portret" w badaniach się po prostu nadzwyczajnie ustalił. Zgodnie z nim, Norwid to trochę ,romantyczny centaur”, ma w sobie co nieco z Mickiewicza i co nieco z siebie samego jako jego sędziego, romantyzmu mutatis mutandis Mickiewiczowskiego. Próba interpretacyjna Kasperskiego zatem, próba ,jenaizowania" Norwida, komplikuje obraz całości, czyni go nawet wyrafinowanym, ale też - chyba go zaciemnia. Norwid inspiruje się romantyzmem głębokim, głębinowym, hermetycznym i taki romantyzm znajduje nie tyle u Friedricha Schellinga, bo to zaledwie „Źródłosłów”, bo jeżeli już - to pośrednio, lecz w Anhellim, Balladynie, Królu-Duchu, Beniowskim, czyli w dziełach poetyckich Juliusza Słowackiego, oraz w muzyce Fryderyka Chopina. Przyjaźń między nim a Krasińskim wymaga tutaj oddzielnego komentarza9. Dopóki jednak nie przyjmiemy, że antropologia romantyczna Norwida była antropologią hermetyczną, że patronowali jej Słowacki oraz Chopin, nie Mickiewicz, dopóki nie zrozumiemy, w jaki właściwie sposób jej patronowali, dopóty nie będziemy w stanie odróżnić antropologii romantycznej Norwida od implikowanej tutaj antropologii modernistycznej.

Ta ostatnia powstaje w niejakim oddaleniu od wzorca, tak jak w oddaleniu od wzorca modernistycznego tworzy Norwid - nawet jeżeli pozostaje w Paryżu i, jak uważałby Rzońca, kontaktuje się lub przynajmniej styka z premodernistami tego $\mathrm{czasu}^{10}$. Naiwnością byłoby sądzić, że dzieła Norwida zapisane po śmierci Zygmunta Krasińskiego (które to wydarzenie, właśnie ono, a nie Quidam, kojarzy mi się nieodparcie z wewnętrzną cezurą Norwidowskiej myśli romantycznej $^{11}$ ) przeniosą w skali ,jeden do jednego" wszystko to, z czym zetknąłby się Cyprian Norwid w Paryżu okresu II Cesarstwa. Stygmat, oczywiście, nie będzie przypominał nowel Prospera Meriméego ${ }^{12}$, ale podobnie jak one - będzie usilnie starał się pozostawać eksperymentem nowelowym na miarę Norwidowską, quo modo Norwidae, nawet jeśli Norwid zaangażuje do tego całą romantyczną

\footnotetext{
${ }^{9}$ Podczas gdy można Cypriana Norwida nazywać pierwszym nowoczesnym egzegetą Słowackiego, a to prima facie za sprawą Wykładów o Juliuszu Słowackim oraz Dodatku o „Balladynie”, w odniesieniu do Krasińskiego funkcjonalnymi określeniami opisującymi stosunek Norwida do autora Nie-boskiej pozostają pojęcia mniejszej wagi i kalibru: to pisarska przyjaźń, Norwid jest co najwyżej polemistą wobec Krasińskiego (mimo wszystko polemistą nastawionym przyjacielsko - co widać w perspektywie sporu Norwida i Krasińskiego wokół Irydiona), ale nie egzegetą jego twórczości, jak dzieje się to w wypadku Słowackiego ewidentnie wywołującego w Norwidzie pragnienie stworzenia syntezy tej twórczości.

${ }^{10}$ W. Rzońca, Modernizm Norwida-paryżanina..., w różnych miejscach.

${ }^{11}$ Chciałoby się powiedzieć poetycko: Krasiński, umierając, zwalnia Norwida z obowiązku wiecznej, „romantycznej wachty”. Jest to z jednej strony rodzaj zobowiązania przyjacielskiego, z drugiej zaś - funkcja symboliczna, czysto umowna, symboliczną, na swój sposób umowną postacią pozostaje bowiem w oczach Norwida Krasiński, zwłaszcza w ostatnim okresie jego życia, który dla Norwida jest okresem pracy nad Quidamem, czyli anty-Irydionem.

${ }^{12}$ Chociaż oczywiście można Stygmat pod pewnymi względami, np. cech stylu, narracji, podobnych rozwiązań fabularnych, zestawiać z niektórymi nowelami Meriméego, np. z Podwójna omytka.
} 
maszynerię - problematykę historiozoficzną i etyczną („stygmatu narodów”) na przykład. Można zresztą zakładać i to, że romantyczna antropologia hermetyczna Norwida bazująca na twórczości Słowackiego oraz Chopina musiałaby ewoluować w sposób adekwatny, to jest w bliźniaczą, modernistyczną antropologię hermetyczną. Tę drogę świetnie rozpoznawał francuski parnasizm i symbolizm. Hermetycznym prądem modernizmu, najdoskonalej skonceptualizowanym w łonie całej epoki, był właśnie symbolizm literacki, i zatem gdzie po Królu-Duchu mógłby kierować się Norwid, szukając własnej koncepcji szczegółu, konkretu poetyckiego, jak nie w stronę Baudelaire'a czy też jemu podobnych młodych, parnasizujących jeszcze (pół-)symbolistów minorum gentium? Co jasne, wybory osamotnionego nawet pośród polskich emigrantów Norwida mogły być przypadkowe, nic bowiem nie dowodziłoby jego rozeznania w młodej poezji francuskiej tego czasu, duch epoki przejawiał się jednak wówczas także w tekstach o wiele słabszych, niższych aniżeli słynne Les fleurs du mal. I nawet brak dowodu lektury Baudelaire'a przez Norwida nie przekreśla możliwości konstatacji, że Vade-mecum było swego rodzaju odpowiedzią (,auratyczną" odpowiedzią, odpowiedzią wynikającą z literackiej ,,aury czasu”) na centon Francuza, że było - powiedzmy to wreszcie - polskimi „kwiatami dobra" ${ }^{\prime 13}$.

Rzecz jasna, mówiąc o modernizmie Cypriana Norwida, poruszamy się w obrębie samych przypuszczeń, przypuszczeń nieraz wzmacnianych niepełnoprawnie za sprawą przesłanki, a nie dowodu. Na porządku dziennym są tu zatem błędy w rodzaju petitio principii, których norwidologia bynajmniej się nie ustrzegła (celuje w nich niestety monografia Wiesława Rzońcy). Sprawa skomplikowana jest jednak także ze strony badaczy romantyzmu Norwida, skupionych do tego stopnia na duplikowaniu licznych przecież potwierdzeń dla swojej przesłanki (nietrudno o to w skali twórczości „dziewiętnastowiecznej” z definicji), że wytracających wątek Norwidowskiej antycypacji modernizmu. Sposobności tymczasem do - jak ująłem to - antycypowania tego zupełnie nowego, nowoczesnego dla Norwida nurtu było zaiste wiele. Pojawiały się nie tylko w kręgu francuskim i nie tylko po napisaniu przezeń poematu Quidam. Chociażby wizyta Norwida w londyńskim Pałacu Kryształowym, która musiała się odbywać pomiędzy 3 a 13 grudnia 1852 roku, a więc dopiero co po napisaniu poematu Promethidion, może okazać się dla poety przykładem granicznego doświadczenia nowoczesności. Więcej: może być ona przykładem lekcji tego, co w teorii sztuki dla Norwida najbardziej istotne i własne - to jest (ujmijmy rzecz metaforycznie) „eschatologii nowoczesności”. Roberto Salvadori w swoim cennym studium na

${ }^{13}$ Dyskusja o związkach łączących światopoglądy Baudelaire’a i Norwida trwa już dosyć długo (Hans Robert Jauss, Rolf Fieguth, Józef Fert etc.). Przywołajmy najnowszą pracę na ten temat: M. Siwiec, Norwid i Baudelaire. Komparatystyka przetomu, w: Komparatystyka dzisiaj, t. II: Interpretacje, red. E. Kasperski, E. Szczęsna, Dom Wydawniczy Elipsa, Warszawa 2011, s. 213-231. 
temat mitu pierwotnego Crystal Palace, nazywa wzniesiony wspólnym trudem londyńczyków gmach ,arcydziełem konstruktorskiej śmiałości i poetyckiego liryzmu” oraz ,najbardziej sugestywnym archetypem nowoczesnej architektury"14. W tym wypadku chlubne miejsce pierwsze rzeczywiście zobowiązuje:

Dokonał się cud. Na trawie, pośród drzew Hyde Parku, wyrosła jak za dotknięciem czarodziejskiej różdżki ogromna szklana konstrukcja. Wsparta na ledwie widocznych, cienkich metalowych belkach, o miękkich, harmonijnych liniach i pełnych wdzięku łukach, tak lekka, jakby nic nie ważyła, lada chwila gotowa poderwać się do lotu. Jej kolor, błękit nieba odbity w szkle i błękit belek, dawał efekt oślepiającej jasności, połyskliwego splendoru. Tryumf lekkości i światła ${ }^{15}$.

Jak mógł przyjmować to doświadczenie Norwid, autor dobrze zapoznanej poetyckiej frazy o ,łagodnym oku błękitu’? Jak uważa Anna Krasuska, ,łagodne oko błękitu" z Norwidowskiego wiersza W Weronie (a wiersz powstał jeszcze w latach 40. XIX wieku) mogło zostać przez Norwida ,zapożyczone”, i to z jednego z włoskich obrazów oglądanych być może w trakcie podróży poety po Italii. Chodzi o Apoteoze Wenecji Paula Veronese’a. Młoda badaczka dzieła Norwida skrupulatnie wyjaśnia, że:

Obraz stanowił gloryfikację władzy i przedstawiał arystokratyczne rody Wenecji, których historię poruszał Norwid w swoim wierszu. Ponadto, mniej więcej pośrodku obrazu, widać było skrawek bardzo jaskrawoniebieskiego nieba. To on przede wszystkim przykuwał uwagę, jego kolor był nadmiernie jasny, wręcz niespotykany. Został on wpisany w formę zbliżoną do wyglądu ludzkiego oka. Znajdował się tuż nad głowami ludzi stojących przy balustradzie, którzy reprezentowali na obrazie arystokratyczne rody miasta ${ }^{16}$.

W wierszu W Weronie ,łagodne oko błękitu” „zrzuca” w końcu ,,ze szczytu gwiazdę”, która „spada i groby przecieka” (II 22) ${ }^{17}$. Zaskakującą repetycję tego

${ }^{14}$ R. Salvadori, Crystal Palace: mit pierwotny, w: tenże, Mitologia nowoczesności, przeł. H. Kralova, Fundacja „Zeszytów Literackich”, Warszawa 2004, s. 10.

15 Tamże.

${ }^{16}$ A. Krasuska, artykuł niepublikowany [rozdział rozprawy doktorskiej pt. „Cyprian Norwid w perspektywie parnasizmu francuskiego", przygotowywanej pod kierunkiem prof. Wiesława Rzońcy w Instytucie Literatury Polskiej UW]. Zob. także: M. Maciejewski, Norwidowskie „łagodne oko błękitu”, w: Liryka Norwida, red. P. Chlebowski i W. Toruń, Towarzystwo Naukowe KUL, Lublin 2003, s. 25-40.

17 Teksty Norwida cytuję według wydania: C. Norwid, Pisma wszystkie, zebrał, tekst ustalił, wstępem i uwagami krytycznymi opatrzył J.W. Gomulicki, t. I-XI, Państwowy Instytut Wydawniczy, Warszawa 1971-1976. Miejsca cytowanych tekstów oznaczam skrótem, w którym liczba rzymska oznacza tom, arabska - stronę. 
motywu w rzeczywistości mógł Norwid obserwować właśnie w Pałacu Kryształowym. Opis podobnego rodzaju doświadczenia podczas podróży po wnętrzach gmachu pozostawia Lothar Bucher:

Jeśli opuścimy wzrok niżej, napotkamy żelazne, pomalowane na niebiesko belki. Początkowo następują po sobie w znacznej odległości; potem cisną się coraz gęściej, póki nie przerwie ich biegu oślepiający snop światła - transept - rozpływający się $\mathrm{w}$ dalekim tle, w atmosferze ziemskiej, która wchłania każdy naturalny element ${ }^{18}$.

Bucher opisuje wreszcie nowoczesną grę architektów Crystal Palace z perspektywą, nowoczesną do tego stopnia, że skróty zastosowane przez nich okazują się skrótami antyperspektywicznymi (sic!) - ci, którzy percypują głębię przestrzeni nad nimi, pozbawieni niemal całkowicie gry światłocieni, nie są w stanie oszacować odległości, jaka dzieli ich od kopuły budynku. Dość powiedzieć, że wiele podobnych chwytów stosował w poezji Norwid, i w realizacji tej oto strategii być może nie inspirował go bynajmniej perspektywizm włoski zaobserwowany podczas podróży po Italii: florencki, wenecki, rzymski, lecz antyperspektywizm budowniczych Kryształowego Pałacu. Koronnym zupełnie przykładem tego sposobu obrazowania pozostaje niezmiennie w tej twórczości Dziecię i krzyż:

Możemy dostrzec delikatną sieć linii, ale nie mamy klucza, by ocenić ich odległość od oka i prawdziwe wymiary. Boczne ściany zbyt są od siebie odległe, by można je było objąć jednym spojrzeniem. Zamiast biec od jednej ściany do drugiej, wzrok szybuje w niekończącej się perspektywie, która niknie na horyzoncie. Nie jesteśmy w stanie stwierdzić, czy ta budowla wznosi się nad nami na wysokość stu czy tysiąca stóp, i czy dach jest płaski, czy żebrowany, bo nie ma tu gry cieni, która by pozwoliła naszym nerwom wzrokowym ocenić rozmiary ${ }^{19}$.

W wierszu Norwida redagowanym po raz pierwszy w 1866 roku czytamy:

Patrz, jak się zmienia:

Oto - wszerz i wzwyż

Wszystko toż samo, $*$

Gdzież podział się krzyż?

*

Stał się nam: bramą.

${ }^{18}$ R. Salvadori, dz. cyt., s. 12.

19 Tamże. 
To, co rzeczywiście być może fascynuje Norwida formalnie, wywołuje prawdopodobnie zarazem jego poznawczą repulsję - zwłaszcza w aspekcie moralnym. Krótki, ale znaczący epizod wizyty Norwida w Pałacu Kryształowym mógłby zresztą posłużyć za asumpt do stworzenia całkiem porywającego eseju porównującego modernizm jego z modernizmem Stefana Żeromskiego. Sednem zestawienia byłyby oczywiście „szklane domy”, owa „szklanodomowość”, przejęta z doświadczenia Crystal Palace, realizowałaby się u Cypriana Norwida na wielu polach - między innymi w lirykach, które eksponowałyby „,szklanodomowy” salon. Dokumentowałyby ten rodzaj aplikacji motywu leksemy: „kryształowy” i „kryształ”, często stosowane w podobnym odniesieniu w tej twórczości ${ }^{20}$. „Szklanodomowa” zapewne mogłaby w tym łańcuchu skojarzeń okazać się także łza, i jako „łza z kryształu”, nigdy notabene niezaistniała w liryce Norwida, stanąć obok słynnej Norwidowskiej „łzy z wosku”. Czyż bowiem kończąca wiersz Po balu strofa zaczynająca się od słów „Otworzyłem okna z drżeniem szkła...” nie wskazywałaby charakterystycznej, deprecjonującej przemiany - łza opadająca z kandelabrów powinna być „łzą kryształową”, skoro z kryształów spada? Rozczarowanie podmiotu lirycznego jest mimo wszystko rozczarowaniem dobrze mu znanym, ta łza bowiem (mówiłby podmiot Norwida) jest zwykłą, materialną, ziemską oraz przyziemną „łezką" z wosku, „łezką” ze świecy stojącej w kandelabrowym, kryształowym uchwycie:

Otworzyłem okna z drżeniem szkła,

Że aż gmach wstrzęsła moja siła:

Z kandelabrów jedna spadła łza --

Ale i ta jedna $-\mathrm{z}$ wosku była!

To jednak wciąż zaledwie detale. Wizyta Cypriana Norwida w Pałacu Kryształowym mogła być dla niego samego po prostu wstrząsająca. Taką była dla Fiodora Dostojewskiego, w którego wyobraźni „sen o przezroczystości zmienił się w totalitarny koszmar zlodowaciałego społeczeństwa"21. Dokumentują tę pisarską traumę Zapiski z podziemia i jako takie stanowią jedno z najbardziej

${ }^{20}$ Krysztat, kryształowy [hasła] w: J. Puzynina, T. Korpysz, Internetowy słownik języka Cypriana Norwida, Pracownia Słownika Języka Norwida, Wydział Polonistyki, Uniwersytet Warszawski, Warszawa 2009, http://slownikjezykanorwida.uw.edu.pl/ [dostęp: 19.06.2016]. Np. w Tajemnicy lorda Singelworth, noweli, która będzie w tym studium przedmiotem szczególnej refleksji: „Żadnej kartki muzycznej, żadnej książki, albumu, ryciny... karty wizytowej etc. ..., posadzka jedynie mozaikowa odzwierciedlała wszystkie meble, polerowne jak kryształ, zaś poutwierdzane w ścianach weneckie zwierciadła odzwierciedlały znowu wszystkość, a ta, razem, więcej świetną i jasną była niż uroczą (VI 157).

${ }^{21}$ R. Salvadori, dz. cyt., s. 15. 
przenikliwych rozpoznań projektu eschatologicznego wpisanego w nowoczesność: ,«człowiek z podziemia» Dostojewskiego rozbijał w ten sposób na kawałki kryształ postępu i przeczuwał, jakie śmiertelne rany mogłyby zadać egzystencji jednostki odłamki zbyt przezroczystych falansterów"22 - powiadał w związku z tym Salvadori. Na gruncie zestawień Norwida z Dostojewskim rzetelnie, choć dyskusyjnie, a zarazem całkowicie kontradyktorycznie do myśli tutaj poprowadzonej, ten problem przedstawiła Ewangelina Skalińska:

Dostojewski, pisząc zupełnie wprost, wydaje się przerażony scenami, które ma okazję obserwować w miastach zachodnioeuropejskich. Szczególnie mocno na jego wyobraźnię oddziałuje „zsyntetyzowana” przestrzeń Kryształowego Pałacu. To miejsce wzbudza w nim wręcz coś w rodzaju „lęku metafizycznego”, wypływającego z głębokiego przekonania o tym, że współczesna mu cywilizacja zupełnie utraciła swoje podstawy chrześcijańskie i wielbiąc osiągnięcia techniczne, oddaje hołd fałszywemu Bogu. [...] Z kolei Norwida nowoczesność nie przeraża. Polski poeta patrzy na współczesne mu zjawiska cywilizacyjno-kulturowe w sposób obiektywizujący; postrzega je na całościowym tle dziejów ${ }^{23}$.

Pomimo tych konstatacji, niejako w kontrze do nich, może warto by zastanowić się nad tym, jak daleko sięgać mogłyby rozpoznania Norwida w tej kwestii. Wydaje mi się bowiem, że i w tym wypadku trzeba by wskazać przede wszystkim na jego myślową niezależność od Dostojewskiego, po drugie - uznać także w nim, Norwidzie, i to jeszcze przed opublikowaniem przez Dostojewskiego Zapisków z podziemia, istnienie „lęku metafizycznego" wywołanego skalą rewolucji nowoczesnej. Ośmielam się twierdzić, że równolegle z Dostojewskim, pod wpływem zobaczenia Pałacu Kryształowego, Norwid tworzy swój własny autorski projekt eschatologicznego ujmowania nowoczesności. Pod tym pojęciem rozumiem natomiast fakt o szerszej skali, a także oddziaływaniu. Jest to fakt (powszechnego zupełnie) odkrycia przez współczesnych Norwidowi i Dostojewskiemu, że tak zwane dzieło nowoczesne zawiera w sobie swój własny początek oraz koniec rozumiane w „znaczeniu temporalnym”, nie zaś „wiecznym”, mimo że skądinąd usiłowałoby ono aspirować do bycia „Alfą i Omegą” (w znaczeniu

22 Tamże, s. 14.

${ }^{23}$ E. Skalińska, Zbliżenie siódme: Norwida i Dostojewskiego wizja cywilizacji i nowoczesności dziewiętnastowiecznej, w: taż, Norwid - Dostojewski. Zbliżenia i rekonstrukcje, Wydawnictwo Uniwersytetu Kardynała Stefana Wyszyńskiego, Warszawa 2014, s. 341-342. Skalińska pojmuje kategorię nowoczesności bardzo szeroko, eksplikując ją zresztą wyraźnie w sposób ponowoczesny (za Michelem Foucaultem). Mimo wszystko zastrzega: „,nie idzie mi o przykładanie współczesnych kategorii literaturoznawczych do zjawisk XIX-wiecznych, tylko o swoiście ogólnoludzkie odczucie nowoczesności” (tamże, s. 325). Wskutek generalizacji termin niezależnie od erudycji autorki w dziedzinie komparatystyki twórczości Norwida i Dostojewskiego pozostaje więc niedookreślony. 
pokrewnym dziełom Mallarmégo $\left.{ }^{24}\right)$. W ramach ustalania poetyki tak zwanego utworu nowoczesnego zakłada się bowiem w jego ramach wewnętrzną celowość i swoiście pojętą „wieczność formy” na podstawie mniemania o jej twórczym, wielokrotnym przepracowaniu.

To odkrycie, demistyfikujące i demitologizujące jednocześnie, czyni dziewiętnastowiecznych „modernistycznych eschatologów” awangardą argonautów nowoczesności. Dostojewski zapoczątkowuje ten proces „eschatologizacji modernizmu" Zapiskami z podziemia w 1864 roku, czyni to jednakże na gruncie europejskim. Norwid cztery lata wcześniej na gruncie polskim inicjuje eschatologiczną refleksję nad nowoczesnością utworem Cywilizacja. Co rozpoczyna zaś Cywilizacja, wieńczy dopiero Tajemnica lorda Singelworth. Czyż tajemniczy Singelworth bowiem to nie klasyczny Man of $1851^{25}$, wychowywany w dobie „kryształowego kultu” (skoro akcja noweli rozgrywa się w Wenecji lat 80. XIX wieku), dziś podróżujący balonem aeronauta, reprezentant „kryształowej metafizyki"? Pamiętajmy (przywoływane tu już jeden raz) słowa Roberto Salvadoriego: Crystal Palace był „triumfem lekkości i światła” i sprawiał wrażenie „konstrukcji” tak „wdzięcznej”, że aż „gotowej poderwać się do lotu” ${ }^{26}$. Dokładnie tak jak lordowski balon, którym podróżował ekstrawagancki ni to arystokrata, ni to nuworysz. „Metafizyka kryształowa” Singelwortha była nie tylko klasyczną metafizyką dychotomiczną, lecz także - zręcznie potrafiła się „posłużyć” przemocą symboliczną, dzieląc porządki na „czyste” oraz „nieczyste”. Ów pierwszy reprezentowany był przez apoteozę „włókien, kryształów, kropli, ruchu, pary, pędu" (VI 160). Ten drugi - przez obrazy miast wznoszonych na „kloakach”, na „leniwych ramionach rozkładających się olbrzymów”, „wciąż gnijących Laokoonach"27 (VI 158-159) etc.:

Improwizator Toni di Bona Grazia z większym niż kiedy zapałem głosił, że ulatujący podróżnik jest mężem misji, jest uprzedzicielem i zwiastunem Wielkiej

${ }^{24}$ Warto w tym kontekście problemów sięgnąć do istotnej w obszarze norwidologii rozprawy Piotra Śniedziewskiego: P. Śniedziewski, Mallarmé - Norwid: milczenie i poetycki modernizm we Francji oraz w Polsce, Wydawnictwo Naukowe Uniwersytetu Adama Mickiewicza, Poznań 2008.

25 Termin zapożyczam z prac anglojęzycznych na temat wiktoriańskiego przełomu nowoczesnego. A. Briggs, The Crystal Palace and the Men of 1851, w: taż, Victorian People. A Reassesment of Persons and Themes, 1851-67, Penguin Books Ltd., Harmondsworth, 1970, s. 45.

${ }^{26}$ Zob. przypis 16 .

${ }^{27}$ Warto zauważyć, że motyw „wciąż gnijącego Laokoona” jako makabrycznego fundamentu, kamienia węgielnego miasta nowoczesnego zapośrednicza dwie równorzędne Norwidowskie fascynacje: zainteresowanie modernizmem oraz klasycyzmem (antykiem w ujęciu klasycystycznym). Jak pisze Rolf Fieguth, twórczość Norwida legitymuje się „,echami osobliwie klasycyzującymi, które czasami przybierają charakter estetycznie agresywnego archaizmu i śmiałego eksperymentu literackiego". Za ich sprawą Norwid ,jasno i dobitnie wskazuje paralelę”, a nawet „utożsamia” „kryzysowy stan antyku” z „kryzysem świata nowoczesnego” - R. Fieguth, Od „Pompei” do „Quidama”. Z problemów klasycyzmu norwidowskiego, w: Klasycyzm ..., s. 372-373. 
Epoki nowej, która ma stać się dla ludzkości rodzajem puryfikacji i czymś do Revivalu amerykańskiego podobnym...

Trudno chyba o dobitniejszy dowód na to, że Cypriana Norwida tak zwana eschatologia modernizmu istotnie zajmowała. Jakkolwiek - od czasu napisania Cywilizacji doszło do znaczących przesunięć. Katastrofizm jako odpowiedź na finał nowoczesnych losów człowieka i świata, który przynosiła Cywilizacja, został zastąpiony niespotykaną zupełnie w skali europejskiej modernistyczną dystopią, którą słusznie przecież mogłaby się wydawać Tajemnica lorda Singelworth. Dlaczego określam tę nowelę mianem dystopii? Co w Tajemnicy... jest dystopijne lub dystopizowane? Chyba ów eschatologiczny witalizm i optymizm, któremu przede wszystkim towarzyszy cytowana powyżej tromtadracja di Bona Grazii, zupełnie bezwarunkowo (jak można mniemać) oddanego wymowie kolejnych pan-symboli Singelwortha (czystość - nieczystość, niskość - wysokość, zło - dobro; VI 158-160). Tu - odmiennie aniżeli w Cywilizacji - Norwid jawi się już jako bardziej wyrafinowany „eschatolog modernizmu”, zniuansowany i wieloznaczny, sprawnie łączący groteskowość, a także palinodyjność narracji, operujący ironią oraz patosem równolegle, nierozłącznie, syntetycznie. Jest tutaj „eschatologiem” dojrzałym, nie zaś naiwnym, walczącym z pierwocinami premodernizmu z ufnym przekonaniem, że skrajności zawarte w owym poglądzie na świat dają się wyrugować, są wyłącznie efemeryczne (obraz katastrofy w Cywilizacji przypominałby pod tym względem obraz biblijnego potopu, który zamyka stare i otwiera nowe).

Singelworth w momencie budowy Crystal Palace mógł mieć kilka bądź kilkanaście lat, można go więc nazwać dzieckiem „kryształowego kultu”. I właśnie on - spadkobierca „kryształowej metafizyki”, dojrzewający w cieniu Kryształowego Pałacu - w ostatnim passusie noweli jawi się oglądającym jako „maleńki i mdły punkcik znikający w przestworzu" (VI 161). Narrator noweli skrupulatnie objaśnia: „był to balon lorda Singelworth” (VI 161) i chyba trudno o bardziej przekonujący przykład zużytkowania przez Norwida mechanizmu litoty, tu służącej pisarzowi do „eschatologicznego rozliczenia” z modernizmem. Nie znaczyłoby to chyba jednak, że Norwid był antymodernistą. Równie daleki jestem od stwierdzeń, że jego twórczość reprezentuje model antyromantyczny. Zaryzykowałbym raczej tezę, że jako „eschatolog modernizmu” rzekłby o nim, podobnie jak o swojej twórczości: „Syn - minie pismo, lecz ty spomnisz, wnuku” (II 17). Norwid oczekiwałby więc późnego, modernistycznego wnuka, modernizmu dojrzałego, świadomego swojej skończoności, to jest temporalności - skończoności tradycji, z której czerpie, oraz skończoności przyszłości, którą ma przed sobą (zauważmy niejako na korzyść dla Wiesława Rzońcy, autora Norwida - poety pisma. Próby 
dekonstrukcji dzieła ${ }^{28}$, że za owego „późnego wnuka” modernizmu mógłby przecież uchodzić... postmodernizm).

By wszystko pozostawało jednak jasne - w moim przekonaniu równolegle należy tu mówić o dwóch istotnych modelach twórczości Norwida. Autor Bransoletki z łatwością bowiem daje się zaklasyfikować jako pisarz szeroko pojętej dziewiętnastowieczności: jest sędzią modernizmu, ale i sędzią romantyzmu, jest ,eschatologiem modernizmu”, ale i „eschatologiem romantyzmu”, wreszcie nie tylko oczekuje „późnego wnuka” modernizmu (a więc postmodernizmu?), lecz także - analogicznie - „późnego wnuka” romantyzmu (czyli neoromantyzmu?). Dążyć więc powinniśmy do utrwalenia podwójnego modelowania twórczości Norwida, zamiast tego jednak (jako norwidolodzy) staramy się wyznaczyć interpretacje dominujące, hierarchizować Norwidowski sposób widzenia świata, uprawiać swego rodzaju przemoc symboliczną i paradygmatyczną. Potrzeba tymczasem „dwuparadygmatycznego” - jeżeli wolno tak rzecz określić - spojrzenia na Norwida, romantyczno-modernistycznego. Głos na temat premodernizmu i modernizmu Norwida jednak (proszę wybaczyć generalizację) stale ginie w dyskusji. Trudno jakkolwiek mówić o modernizmie tego rodzaju, „modernizmie rozmytym” w sposób precyzyjny. Być może pomocne okażą się etykiety, propozycje uszczegółowień, wskazywanie na przykład antropologii bądź też teleologii specyficznie modernistycznych, które u Norwida dałoby się odnotować. Niech jednym z takich wstępnych rozpoznań, widzeń, postrzegań stanie się moja próba zobaczenia Norwida jako „eschatologa modernizmu” (na zupełnie innych prawach niż te widoczne i skonstatowane u Fiodora Dostojewskiego $\left.{ }^{29}\right)$.

${ }^{28}$ W. Rzońca, Norwid - poeta pisma. Próba dekonstrukcji dzieła, Wydawnictwo Naukowe Semper, Warszawa 1995.

${ }^{29} \mathrm{~W}$ studium nie pojawia się żadne odwołanie do słynnego, prekursorskiego dla wątków nowoczesności Norwida studium Zofii Stefanowskiej pt. Pisarz wieku kupieckiego i przemysłowego. Wynika to z paru powodów: po pierwsze - intencją autora studium jest odzwierciedlenie aktualnego stanu badań nad modernizmem Norwida, a tę warstwę tworzą prace badaczy takich jak Rzepczyński, Kuziak, Fieguth, Śniedziewski, Rzońca, Skalińska etc.; po drugie - rozprawa Stefanowskiej, znakomita skądinąd, jest prima facie wskazaniem na siłę romantyzmu mickiewiczowskiego w twórczości Norwida (tymczasem ja usiłowałem od tego sposobu myślenia odejść, wskazując na przejmowanie przez Norwida wzorców romantyzmu głębinowego, hermetycznego i uniwersalnego, nie powszechnego: reprezentowali te typy Słowacki oraz Chopin, i to oni otwierali [być może] Norwida na modernizm); po trzecie - tekst Stefanowskiej zbyt silnie, zbyt jednostronnie wskazuje, na to, że temat „Norwid modernistyczny” redukuje się nie tyle do modernizmu samego Norwida, lecz do określonego typu lektury jego dzieł (wyłącznie) - dokonanej przez „modernistów polskich" pod wpływem legendy autora Assunty, modelowanej przez młodopolskiego edytora jego pism, Zenona Miriama-Przesmyckiego. Zob. Z. Stefanowska, Pisarz wieku kupieckiego i przemystowego, w: taż, Strona romantyków. Studia o Norwidzie, Towarzystwo Naukowe KUL, Lublin 1993, s. 5-53. 


\section{Bibliografia}

Norwid Cyprian, Pisma wszystkie, zebrał, tekst ustalił, wstępem i uwagami krytycznymi opatrzył Juliusz Wiktor Gomulicki, t. I-XI, Państwowy Instytut Wydawniczy, Warszawa 1971-1976.

Briggs Asa, The Crystal Palace and the Men of 1851, w: taż, Victorian People. A Reassesment of Persons and Themes, 1851-67, Penguin Books Ltd., Harmondsworth 1970, s. 15-51.

Fieguth Rolf, Od „Pompei” do „Quidama”. Z problemów klasycyzmu norwidowskiego, w: Klasycyzm. Estetyka - doktryna literacka - antropologia, red. K. Meller, Wydawnictwo Neriton, Warszawa 2009, s. 345-374

Junkiert Maciej, Grecja i jej historia w twórczości Cypriana Norwida, Wydawnictwo Naukowe Uniwersytetu im. Adama Mickiewicza, Poznań 2012.

Kasperski Edward, Pseudo-Norwid, czyli co się komu podoba, „Studia Norwidiana” 2014, nr 32, s. $290-325$.

Kasperski Edward, Stowne obrazy Norwida. Szkic z poetyki komparatystycznej, w: tenże, Kategorie komparatystyki, Wydawnictwo Wydziału Polonistyki UW, Warszawa 2010, s. 263-268.

Kuziak Michał, Norwid i pejzaż nowoczesności. Wokół Paryża poety, „Studia Norwidiana” 2014, nr 32, s. 61-81.

Kuziak Michał, Palimpsesty komparatystyki, w: Komparatystyka dzisiaj, t. I: Problemy teoretyczne, red. E. Szczęsna i E. Kasperski, Universitas, Kraków 2010.

Maciejewski Marian, Norwidowskie ,łagodne oko błękitu”, w: Liryka Norwida, red. P. Chlebowski i W. Toruń, Towarzystwo Naukowe KUL, Lublin 2003, s. 25-40.

Mackiewicz Tomasz, Sokrates Norwida. Kontekst - recepcja - kontynuacja, Wydawnictwo Wydziału Polonistyki UW, Warszawa 2009.

Puzynina Jadwiga, Korpysz Tomasz, Internetowy słownik języka Cypriana Norwida, Pracownia Słownika Języka Norwida, Wydział Polonistyki UW, Warszawa 2009, http://slownikjezykanorwida.uw.edu.pl/ [dostęp: 19.06.2016].

Rzepczyński Sławomir, Norwid a nowoczesność, w: Romantyzm i nowoczesność, red. M. Kuziak, Universitas, Kraków 2009, s. 185-215.

Rzońca Wiesław, Modernizm Norwida-paryżanina w świetle młodopolskiego neoromantyzmu (Paul Verlaine w ujęciu Tadeusza Żeleńskiego), w: tenże, Premodernizm Norwida - na tle symbolizmu literackiego II połowy XIX wieku, Wydawnictwo Wydziału Polonistyki UW, Warszawa 2013.

Rzońca Wiesław, Norwid - poeta pisma. Próba dekonstrukcji dzieła, Wydawnictwo Naukowe Semper, Warszawa 1995.

Rzońca Wiesław, Premodernizm Norwida - na tle symbolizmu literackiego II połowy XIX wieku, Wydawnictwo Wydziału Polonistyki UW, Warszawa 2013.

Salvadori Roberto, Crystal Palace: mit pierwotny, w: tenże, Mitologia nowoczesności, przeł. H. Kralova, Fundacja „Zeszytów Literackich”, Warszawa 2004.

Siwiec Magdalena, Norwid i Baudelaire. Komparatystyka przełomu, w: Komparatystyka dzisiaj, t. II: Interpretacje, red. E. Kasperski, E. Szczęsna, Dom Wydawniczy Elipsa, Warszawa 2011, s. 213-231.

Skalińska Ewangelina, Norwid - Dostojewski. Zbliżenia i rekonstrukcje, Wydawnictwo Uniwersytetu Kardynała Stefana Wyszyńskiego, Warszawa 2014.

Stefanowska Zofia, Pisarz wieku kupieckiego i przemystowego, w: taż, Strona romantyków. Studia o Norwidzie, Towarzystwo Naukowe KUL, Lublin 1993, s. 5-53. 
Cyprian Norwid w Crystal Palace albo czy istnieje światopogląd modernistyczny... 343

Śniedziewski Piotr, Mallarmé - Norwid: milczenie i poetycki modernizm we Francji oraz w Polsce, Wydawnictwo Naukowe Uniwersytetu im. Adama Mickiewicza, Poznań 2008.

Trybuś Krzysztof, Norwidowski klasycyzm - zarys problemu, w: Klasycyzm. Estetyka - doktryna literacka-antropologia, red. K. Meller, Wydawnictwo Neriton, Warszawa 2009, s. 375-390.

\section{Karol Samsel}

\section{Cyprian Norwid in Crystal Palace or does the Norwid's modern view of the world exist?}

\section{(Summary)}

The author of the article aims to add his voice to the debate (fundamental for the studies of Norwid) on the tangled historical and literary origin of Cyprian Norwid and methods of legitimising it: the romantic and modernist. Although the text is clearly seeking a new language to talk about Norwid's association with the subsequent modernist era (to describe Norwid's case the author uses the term "fuzzy modernism," while calling the poet himself " an eschatologist of modernism," distinct in this respect from the apparently similar Fyodor Dostoyevsky - modernist eschatologist), the ultimate conclusion is the Polish poet should be placed in the contaminated trend. Also suggested is a need for a study of his literary works that would provide a double model of the nineteenth background of Norwid's text: as romantic, and at the same time modernist. As a symbol of Norwid's modernity's the author chooses London's Crystal Palace, a place that Norwid (like Dostoyevsky) visited between 3 and 13 December 1852.

Słowa kluczowe: Cyprian Norwid; Fiodor Dostojewski; Crystal Palace; modernizm; romantyzm; eschatologia

Keywords: Cyprian Norwid; Fyodor Dostoevsky; Crystal Palace; Modernism; Romanticism; eschatology 